\title{
Classroom Goal Structure and Students' Achievement Goal: A Study of Intrinsic Motivation of Secondary School Students in Nagaland
}

\author{
Vinika Chophy ${ }^{1}$ \\ ${ }^{1}$ Ph.D Scholar, ZHCES/SSS, Jawaharlal Nehru University, New Delhi-110067, India \\ Correspondence: Vinika Chophy, Ph.D Scholar, ZHCES/SSS, Jawaharlal Nehru University, New Delhi-110067, \\ India
}

Received: May 10, 2018

Accepted: August 20, 2018

Online Published: August 21, 2018

doi:10.5539/ijps.v10n3p53

URL: https://doi.org/10.5539/ijps.v10n3p53

\begin{abstract}
The purpose of this research was to explore the mediating effects of promoting interaction between classroom goal structure and students' intrinsic motivation. A conceptual model of the three variables was developed and tested using mediation analysis. Participants included 60 students of age group 12-14 of $8^{\text {th }}$ grade of a private Higher Secondary School. The result of this study revealed that classroom environment affects the perception of the students about their achievement related behavior and outcomes. This further influences the intrinsic motivation of the students. However, the effect of classroom context on students' motivation is not always mediated through promoting interaction. The findings of the present study do not support the results and suggestions of the previous researchers. Finding suggests that there is a need for a rigorous and systematic investigation on the link between classroom goal structure and students' intrinsic motivation by identifying a mediating variable. Also, it may be mentioned that there is a need for taking into consideration both the teachers' classroom and personal goal orientations that affect students' perceptions as this may further influence their learning.
\end{abstract}

Keywords: Classroom goal structure; promoting interaction; mastery and performance goal orientation

\section{Introduction}

Achievement goal is a mental framework within an individual that determines his or her achievement behaviour in any academic settings. It describes what learners orient to in the process of learning, the instrumental role of what is being learned in particular (Winne \& Nesbit, 2010). In order to understand how an individual behaves in the achievement situation, the goal theorists (e.g. Dweck, 1986; Nicholls, 1984) coined the term "Achievement goal theory". It is a framework introduced for understanding the different goal that the students adopt and how it relates to the achievement of an individual. Subsequently, two goals were identified, mastery goal (learning goal) and performance goal (task goal). It appears that the students are open to orient themselves to either of these goals according to the evaluation they make about their own performances in the academic context. However, some studies (see Anderman \& Midgely, 1997, Roeser et al. 1996; Meece et al. 2006), suggested that it is the classroom environment that influences the type of achievement goal which the students adopt. One of such environment can be understood in terms of classroom goal structure. It is defined by how the individual student gives meaning to classroom experiences and what type of motivational orientation they adopt, that is, their classroom goal orientation. As argued by Ames \& Archer (1988), classroom goal orientation is a function of how the individual students interprets and reacts to classroom experiences. It is infact, determined by what is actually happening in the classroom.

Many studies have been conducted and attempt has been made to link classroom goal structure with different variables viz. Achievement goals and Motivational process, Goals and belongingness, Classroom Assessment, Classroom condition or situation, Intrinsic motivation etc. (Ames \& Archer, 1988; Roeser et al., 1996; Linnenbrink, 2005; Elliot \& Murayama, 2009; Alkharusi, 2010). The present study focussed on exploring the relationship between classroom goal structure and intrinsic motivation. However, it is not known how the classroom goal structure influences intrinsic motivation of the students. On the basis of the findings from the previous study (Elliot \& Murayama, 2009; Ryan \& Patrick, 2001; Ohtani et al., 2013), it is hypothesized that the classroom goal structure influences intrinsic motivation of the students when it is mediated by promoting interaction between students and students as well as between students and teachers. Although prior research 
demonstrated the existing relationship between these variables, more research is required to understand these relationships as there are inconsistencies in their study. The present study focussed on the relationship between promoting interaction and students' intrinsic motivation. Also, this study focussed on the mediating effects of promoting interaction between classroom goal orientation and students' intrinsic motivation in the classroom.

\subsection{Achievement Goal Theory}

Achievement goal theory is a theoretical framework which mainly focuses on the way individuals interpret and react to events which may have an effect on the patterns of behavior and their level of competence (Dweck \& Leggett, 1988). Elliot and Dweck contested that a person's achievement goal represent his or her purpose for engaging in behaviour in an achievement situation (Elliot and Dweck, 2005). In their attempt to explain why children of equal ability display divergent responses towards failure, two types of goals were identified; performance goals (also known as task goals) in which the purpose of behaviour is to demonstrate one's competence (or avoid demonstrating one's incompetence), and mastery goals (also known as learning goals), in which the purpose of behaviour is to develop one's competence and task mastery. Previous researchers on achievement goal have focused mostly on the mastery and performance goal dichotomy where mastery goal was considered adaptive and performance goal was considered maladaptive.

Achievement goal constructs including mastery and performance goals mirrors a structured system, theory, or schema for approaching, engaging, and evaluating one's performance in the academic setting. It is in this sense that the term goal orientation theory is often used to signify the idea that these goals include a general orientation to the task and a number of related beliefs about purposes, competence, success, ability, effort, mistakes and principles. Others (e.g., Ames, 1992, in classroom structures) proposed that goals can be more of contextual factors and the functions related to it, and yet some models (e.g., Nicholls, 1990) assumed that goals are a way of viewing success and thus, the judgements of competence, ability and effort flow from these goals (Pintrinch, 2000). It was Elliot \& his colleagues (see Elliot \& Church, 1997; Elliot \& Harackiewicz, 1996; also see Middleton \& Midgely 1997) who suggested that performance goals need to be separated into approach and avoidance performance goals as it was found that these goals may result in contradictory outcomes, yet all of them are not less adaptive as predicted by a standard goal theory.

\subsection{Classroom Goal Structures and Students' Intrinsic Motivation}

The numerous researches (see Ames \& Archer, 1988; Ames, 1992; Dweck \& Leggett, 1988; also see Elliot et al., 1998, Anderman \& Midgely, 1997 etc.) done on the classroom goal and students' motivation based on the achievement goal theory have shown how classroom goal structure have an impact on the intrinsic motivation of the students. Some studies provided evidence that students' personal goal orientations correspond with their perceptions of the classroom goal structure and these relations are found even when differences in student characteristics are controlled (Roeser et al. 1996; Meece et al. 2006). Furthermore, the class contextual features, teachers' teaching experiences and assessment practices were found to be related significantly with students' characteristics in influencing students' achievement goals (Alkharusi, 2008). Pulkka \& Niemivirta (2013) argues that students' personal achievement goal orientations are often associated with the students' self evaluations about their course related performances. As children in the same classroom are treated differently, they have different experiences (Ames, 1992). For instance; in Brophy's (1981) analysis of teacher praise, he argued that praise and reward are equally important but are not evenly distributed. It can thus be interpreted quite differently by students, as a function of their prior experiences.

The existing research on the classroom goal structures and students' achievement goals has linked them with different variables such as classroom environment (Roeser et al., 1996), Praise on intelligence, Motivation process (Ames \& Archer, 1988; Mueller \& Dweck, 1998), Assessment practices (Alkharusi, 2008) etc. However, a common limitation of the previous studies is that they have failed to take into account the teaching strategies of the teachers in the classroom such as promoting interaction. It was on the study conducted by Ohtani et al., (2013) where it was suggested that teachers' promoting interaction can have a positive effect on students' intrinsic motivation and this can lead them towards the achievement outcome. Therefore, it is proposed that encouraging interaction between the teachers and the students and among the students will increase the intrinsic motivation of the students in the classroom. Studies reveal that mastery goal structures lead to adaptive motivational outcomes, where as performance goal structures result in maladaptive behavioural outcome among the students. This indicates that students' perception of goal structure is critical to their motivation and academic achievement (Nitsche et al., 2013). Therefore, in the present study classroom goal structure is in regard to students' perception of teachers' instructional practices. 


\subsection{Classroom Context: Promoting Interaction}

It is an accepted fact that a large amount of the classroom time is assigned to assessment-related activities (Mertler, 2003). Therefore, identifying assessment and teaching practices conducive to the adoption of desirable achievement goals becomes crucial (Alkharusi, 2008). It may be agreed that the assessment and teaching practices of the teacher that include promoting interaction in the classroom, have a strong impact in determining the type of goals that students adopt. The goal orientation that teachers bring in the classroom can also have a mediating effect on the achievement goal of the students in the classroom.

Ohtani (2013) argued that the teachers' promoting interaction mediated the effects of classroom characteristics in mastery goal structures. In contrast, performance goal structures did not predict teachers' promoting interaction or intrinsic motivation at either the classroom or student levels, but it did not have any negative effect on students' motivation. However, some studies (e.g., Kaplan et al., 2002; Roeser et al., 1996; Ryan et al., 1998) on the promotion of classroom interaction have reported the negative effects of performance goal structures on students' motivation (Ohtani et al., 2013). Thus, the mediation processes of promoting interaction are not totally confirmed in a classroom goal structure with students adopting different goal orientations.

James \& Yates (2007) pointed out that the teachers, who involve students, encourage interactions between students, emphasize effort in task engagement, and show support and concern about student learning are thought to exhibit a high mastery focus. Also, they have put in that the learning context is the primary influence on students' outcome including personal goal orientations. In the words of Ryan \& Patrick (2001), "Promoting interaction in the classroom may include students sharing ideas, working together, help-seeking or help giving etc. As such, interaction among the students is a critical component of student-centred instructional approaches."

\subsection{The Present Research}

The present research aimed to contribute to the limited study on how promoting interaction in the classroom mediates the relationship between classroom goal orientation and students' intrinsic motivation. In doing so, this research tried to understand the dynamics of the classroom and how these have an impact on the academic performance of the students. It is often believed that students get highly motivated when the classroom dynamics focus on their goals and interests. The variables selected for this study were classroom goal orientation, promoting interaction and students' intrinsic motivation.

Some studies (Ames \& Archer, 1988; Dweck \& Leggett, 1988) revealed that mastery goals are adaptive and performance goals are maladaptive, while others such as, Elliot et al., (1998); Baron et al., (1997) found that performance goals are not always maladaptive. In fact, both mastery goals and performance goals can have a positive impact on the intrinsic motivation of the students. Further research (Alkharusi, 2008; Nitsche, 2013) showed that the teaching practices of the teachers affect the achievement motivation of the students. The motivational constructs associated with classroom mastery and performance framework are a function of both individual differences in teachers, i.e., experience teaching, as well as variations in the contexts within which teachers work, i.e., academic level (Wolters \& Daugherty, 2007). Furthermore, Roeser et al. (1996) found in their study that students adopt either mastery or performance goals depending on the way they perceive the environment. Giving the recognition and special privileges to those students who are found to be more able may undermine other students' perceptions and may be limiting the number of students who feel a sense of success and belonging at school. Based on the existing theory and literature, the following hypotheses are formulated.

\section{Hypothesis 1: Classroom goal structure predicts students' intrinsic motivation}

It was anticipated that classroom goal structure will have an impact on the intrinsic motivation of the students. The motivation of the students is influenced by many factors in the academic settings. It may be mentioned that one factor that has received widespread attention in the achievement goal theory literature is the classroom goal structure which characterizes the classroom dynamics and how these determines the motivation of the students in the classroom. In a classroom situation, teachers can affect student motivation depending on whether they emphasize on skill development or ability differences. In fact, the classroom goal structures influence student behaviour and determine the type of personal goals that they adopt in the academic settings. However, it is also true that the students' perceptions of the goal dimension of the school environment are strongly related to their perceptions of the relationship dimension of the school environment which clearly indicates that features of the classroom environment can influence the goals adopted and pursued by students (Midgley et al., 1996). 
Hypothesis 2: Promoting interaction mediates the relationship between classroom goal structure and students' intrinsic motivation.

In a combined study of Elliot \& Murayama (2009), they found that a mastery goal structure was a positive predictor of intrinsic motivation and academic self-concept at the direct effect level, and a performance-approach structure was found as the positive predictor at the indirect effect level. But performance-avoidance goals were found as negative predictors at both direct and indirect outcomes. The study conducted by Ohtani et al., (2013) suggested that teacher promoting interaction in the classroom mediates the effect of classroom characteristics (i.e., mastery goal structures) on the students' intrinsic motivation.

On the basis of the existing theory and research, it was predicted that the relationship between classroom goal structure and students' intrinsic motivation will be mediated by teachers' promoting interaction in the classroom.

\section{Hypothesis 3: Classroom interaction is positively associated with students' intrinsic motivation}

Based on the existing study on classroom goal structure and students' motivation, it was predicted that there will be a positive direct relationship between classroom interaction and the intrinsic motivation of the students. The present research on classroom goal structure is explained through a given model.

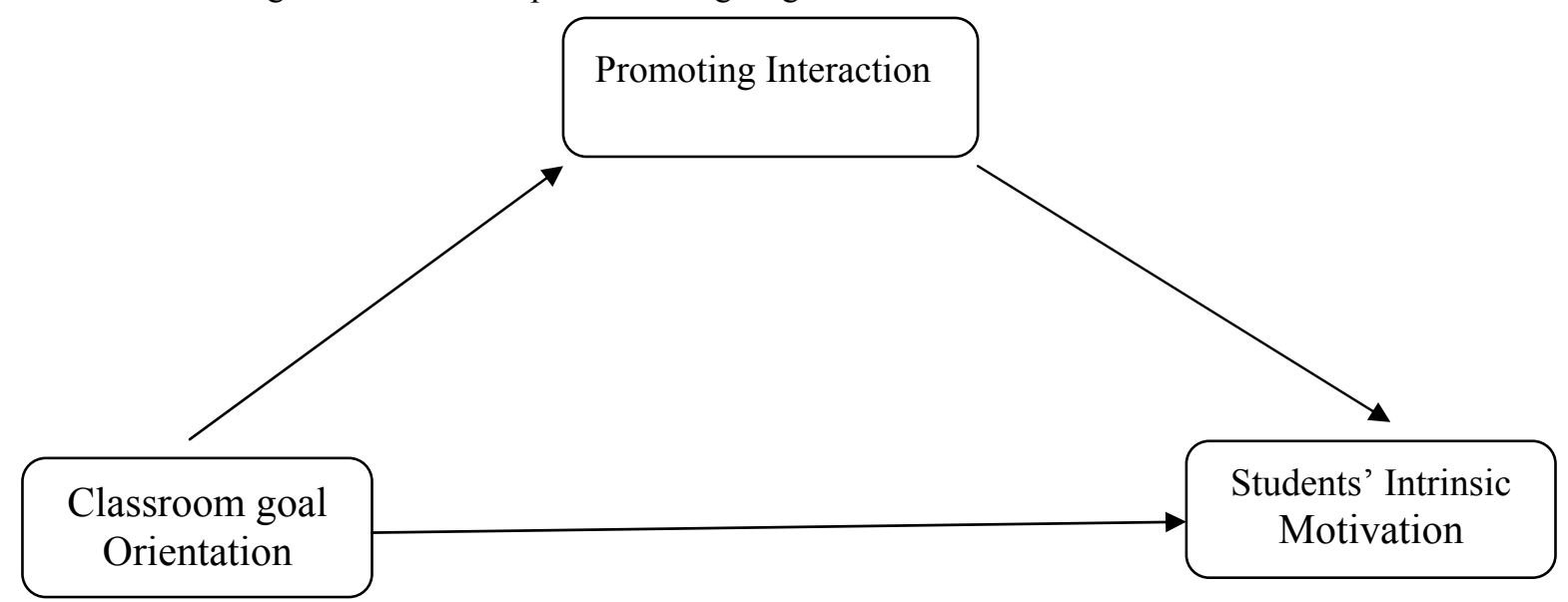

Figure 1. A conceptual framework investigating

the inter-correlations of the three variables and its effect on one another

\section{Method}

\subsection{Participants and Procedure}

The sample size consisted of 60 students (age group 12-14) of $8^{\text {th }}$ grade of a private Higher Secondary School in Nagaland. The participants were of the same class as the present study only focussed on mathematics class. They were assured that their identities will not be revealed and that it will be completely confidential. All three variables were specific to mathematics. The students were provided with three different questionnaires and all variables were analyzed and reported.

\subsection{Measures}

Classroom goal structure: For assessing the classroom goal structure, 14 items were created basing on the Patterns of Adaptive Learning Survey (Midgely et al., 2000). Out of them 7 items assessed mastery goal structure (sample item: My teacher thinks mistakes are okay as long as we are learning.) or (My teacher gives us time to really explore and understand new ideas) and 7 items for assessed performance goal structure (sample item: My teacher points out those students who get good grades as an example to all of us) or (my teacher often gives more time in the class to those who get good marks in mathematics).

Promoting interaction: To assess teachers promoting classroom interaction eight items based on Ryan and Patrick's scale (2001) was adapted. It consisted of 8 items, such as "In math class, our teacher emphasizes the importance of team work" or "In math class, our teacher says that we learn better if discuss and help each other while solving the problem" etc.

Intrinsic motivation: For the assessment of students' intrinsic motivation for learning mathematics, Elliot and Church's scale (1997) intrinsic motivation scale were used. For this purpose of study, 12 items were selected. For example; the items will include, "I enjoy this class a lot" or "I think this class is very interesting". 


\section{Results}

\subsection{Mediation and Inter-Correlations}

The correlation and the mediation were tested for all the three variables to study the inter-correlations. Pearson's correlation method was used to calculate the coefficient of correlations between these variables and linear regression method was used to test how promoting interaction mediates the effect of classroom goal structure and students' intrinsic motivation. For testing the mediation, logic provided by Baron \& Kenny's (1986) was used. To test the mediation, following three regression equations were used:

Promoting interaction $=$ B1Classroom Goal Structure

Intrinsic Motivation $=$ B2Classroom Goal Structure

Intrinsic Motivation = B3Classroom Goal Structure + B4 Promoting Interaction

Baron \& Kenny (1986) also that in order to establish that mediation process does exist following four conditions must be satisfied: (1) B1 must be significant, (2) B2 must be significant, (3) B4 must be significant, and (4) B3 must be smaller than B2. If B3 is reduced to a non-significant effect, full mediation is demonstrated. If B3 is reduced, but still significant, then partial mediation is demonstrated.

\subsection{Preliminary Analysis}

The correlation between classroom goal structure and promoting interaction was examined. Correlation between mediating variable, that is, promoting interaction and the outcome variables, that is, students' intrinsic motivation was also measured. The result obtained from this study showed a positive correlation between classroom goal structure and promoting interaction was almost significant (.25). Also, for intrinsic motivation and classroom goal structure a positive correlation (.56) was found. However, correlation between promoting interaction and intrinsic motivation (.10) as such the reliability of promoting interaction was not fully confirmed. The given table presents results of the final explanatory model of the correlations of the three variables.

Table 1. Correlations among the three variables using Pearson correlation method

\begin{tabular}{lllll}
\hline Variables & $\mathrm{N}$ & Clssrm Goal Structure & Promoting interaction & Intrinsic motivation \\
\hline Clssrm Goal Structure & 60 & 1 & .25 & .56 \\
Promoting interaction & 60 & .25 & 1 & .102 \\
$*_{*} \mathrm{p}<0.01$ & 60 & .56 & .102 & 1 \\
$*_{\mathrm{p}}<0.05$ & & & &
\end{tabular}

Table 1 displays the correlation coefficient for the three variables. The result from this analysis reported that the classroom goal structure effects the students' intrinsic motivation. In addition, it is clearly observed from the obtained result that classroom goal structure is positively significant to intrinsic motivation of the students with a significant correlation $(\mathrm{r}=.56, \mathrm{p}<.01)$. Also, promoting interaction and classroom goal structure was almost significant with a significant correlation $(\mathrm{r}=.25, \mathrm{p}<.054)$. However, the correlation between the intrinsic motivation and promoting interaction was not significant.

\subsection{Mediational Analysis}

The table given below exhibits the values for classroom goal structure and students' intrinsic motivation as hypothesized. Conversely, promoting interaction did not confirm the proposed hypothesis as the tested result revealed no significance between promoting interaction and students' intrinsic motivation. Mean and SD for the classroom goal structure was $(47.05 ; 8.627)$ for the intrinsic motivation mean was $(44.48 ; 9.118)$ and mean for promoting interaction process was $(24.65 ; 8.285)$. 
Table 2. Mean, SD of three variables and Unstandardized regression coefficients from three regression equations

\begin{tabular}{lcccll}
\hline Variables & $\mathrm{N}$ & Mean & $\mathrm{SD}$ & $\mathrm{B}$ & Sig. \\
\hline Clssrm G. Structure & 60 & 47.05 & 8.627 & $\mathrm{~B} 1=.24$ & .054 \\
& & & & $\mathrm{~B} 2=.59$ & .01 \\
$\begin{array}{l}\text { Intrinsic } \\
\text { motivation }\end{array}$ & 60 & 44.48 & 9.118 & & .01 \\
$\begin{array}{l}\text { Promoting Interaction } \\
\mathrm{p}<.01\end{array}$ & 60 & 24.65 & 8.285 & $\mathrm{~B} 4=-.045$ & .722 \\
\hline
\end{tabular}

Mediating effects of promoting interaction - The first step in testing the mediating effects of promoting interaction was to show the effect of classroom goal structure on promoting interaction. The significance shown on table 2 provides initial support for this effect with a regression $(r=.25 ; \mathrm{p}<.054)$. From the first equation it has been observed that classroom goal structure is almost significant $(B 1=.24)$ to promoting interaction between teachers and students and between students and students.

Second, the regression coefficient of classroom goal structure on students' intrinsic motivation was calculated. The relationships between these two variables got support from data as hypothesized. The results of a regression analysis predicting intrinsic motivation from classroom goal structure score has been shown in the table 2 . The zero-order significant correlation between classroom goal structure and intrinsic motivation provides initial support for this effect. B2 $=.59(\mathrm{p}<.01)$ shows that classroom goal structure can predict intrinsic motivation.

Third, the effect of classroom goal structure and promoting interaction on the intrinsic motivation of the students was addressed. The result obtained $\mathrm{B} 3=.60(\mathrm{p}<.01)$ and $\mathrm{B} 4=-.045(\mathrm{P}<.722)$. This indicates that there is a direct effect of classroom goal structure on students' intrinsic motivation as the regression analysis displayed a positive significance. On the other hand promoting interaction had a negative effect on students' intrinsic motivation. However, as the value of B3 is not less than that of B2, it can be said that there is no support for mediation effect of promoting interaction between classroom goal structure and intrinsic motivation of the students (see table 2).

\section{Discussions}

In the present research, a model comprising three variables was proposed and tested in the context of secondary classroom. These three variables include the classroom goal structure, intrinsic motivation and promoting interaction. The results that were obtained provided a strong evidence for one hypothesis, while for the other hypothesis it did not find any strong evidence. The findings from this study indicate that classroom goal structure can influence the intrinsic motivation of the students as it is consistent with the previous studies (Ryan \& Patrick, 2001; Elliot \& Murayama, 2009; Ohtani et al., 2013). However, the hypothesized mediation effect of promoting interaction between intrinsic motivation and classroom goal structure was not confirmed as suggested by the previous researchers.

The results from the direct effect model indicated that classroom goal structure was a direct positive predictor of promoting interaction, and a direct positive predictor of intrinsic motivation. As suggested by Baron \& Kenny (1986), B1 value for classroom goal structure and students' intrinsic motivation is significant. Also, B2 value for classroom goal structure and promoting interaction is significant. This pattern of findings is supported by the several studies in the existing literature (see Elliot \& Harackiewicz, 1996; Elliot \& Murayama, 2009; Elliot et al., 2002; Urdan \& Schoenfelder, 2006; James \& Yates, 2007). Students' perception of classroom goal structure in math class is perceived as supportive where there is emphasis on interaction and sharing of ideas in the classroom by the teacher. If teacher focuses more on mastery goal orientation and fosters sharing of opinions among the students and value them, it will assist them for adaptive patterns of motivation and engagement in the classroom (Ryan \& Patrick, 2001).

No evidence for mediation was found for maths due to a non-significant promoting interaction effect for intrinsic motivation. The value of B4 for promoting interaction and students' intrinsic motivation is insignificant and the B3 value is slightly greater than B2 value. This indicates that promoting interaction in the classroom does not determine the increase or decrease of intrinsic motivation of the students in the classroom while learning mathematics. It can be construed that in the classroom emphasizing interaction among the students, it may encourage the students to work together, help them in sharing and discussing their problems which might affect 
their level of achievement, however, it does not increase the level of intrinsic motivation of the students. The effects of the features of mastery and performance goal structures which are commonly experienced by students in the classroom are not always mediated by the teacher's instructional strategies such as promoting interaction.

From the models that have been analysed, it is apparent that only the first two conditions outlined by Baron \& Kenny (1986) are met since the result for the first two regressions for classroom goal structure on promoting interaction as well as intrinsic motivation had a positive significance. However, it did not yield any significance for promoting interaction on students' intrinsic motivation which clearly indicates that promoting interaction do not have a mediating effect between classroom goal structure and students' intrinsic motivation in a classroom. Also, in the third equation the B3 value of the classroom goal structure is not smaller than the B2 value of the classroom goal structure from the second equation which indicates that there is no mediation effect of promoting interaction between classroom goal structure and students' intrinsic motivation.

\subsection{Integrating the Results with the Existing Literature}

The present research was designed to further an integrative development of classroom goal structure effect on the students' intrinsic motivation, cognition and behaviour by incorporating the interaction process into the mastery and performance goals motivation. Hypotheses were generated for these three variables, and the results provided strong support for classroom goal structure and students' intrinsic motivation, but it did not provide any support for promoting interaction and the intrinsic motivation of the students. Both in the preliminary analysis and mediational analysis, it demonstrated that the interaction process cannot be construed as a mediator of the relationship between classroom goal structure and students' intrinsic motivation.

The finding from this study did not lend empirical support to the previous findings of Ryan \& Patrick (2001), Ohtani et al. (2013). Promoting interaction was found to be less sufficient to help students feel confident in engaging with peers and academic tasks. One reason could be that, in a classroom situation the teachers may be reluctant to allow the students to talk with each other during the academic work as it becomes difficult for them to manage the class (for e.g. this may encourage the students to be off-task and disruptive. It cannot be ignored that the factors outside the classrooms are more important in influencing the relationship with peers than the classroom interaction (Ryan \& Patrick, 2001). The present research does not corroborate the findings and suggestions as given by Ohtani et al. (2013) that promoting interaction can influence the motivation and achievement related behaviours.

According to the findings from the previous researcher (Ryan \& Patrick, 2001), the regular encouragement from the teachers in the classroom to share and discuss the problems relating to their academics among the students can help in motivating them in learning their subjects, especially mathematics. The constant encouragement from the teacher develops a sense of belongingness within the learners and this increases the level of intrinsic motivation and thus affects the achievement level of the learners. However, improper application of the same may perceive the classroom goal messages differently, and the effects of perceived classroom goal structures on motivational and achievement outcomes differs for different students (Urdan, 1999). Urdan (2004a) and Wolters (2004) suggested that there is a greater variety in students' perceptions of the classroom goal structure within the same classroom than there is between different classrooms. From this perspective, it is quite feasible that students' personal goal orientations can affect the goal messages which they perceive in the learning environment. (Urdan \& Schoenfelder, 2006).

The classroom features and the instructional practices of the teachers should allow students to play effective role inorder that they contribute equally towards teaching and learning in the classroom (Ohtani et al., 2013). Nonetheless, the level of perception differs from student to student. As such, schools should provide the children with interactive and encouraging environment where there are opportunities for shared ideas or knowledge as this may help in developing intellectual capacity and competence. At this time of schooling, the teachers and the parents as well emphasize more on relative ability and social comparison in learning situations (Roeser et al., 1996). It is the teachers who structure their classrooms to maximise task involvement. Consequently, this may either enhance the intrinsic motivation or demotivate the students in the classroom depending on the type of environment provided by the teacher in the classroom. Therefore, focussing on both the classroom and personal goals becomes mandatory as this influences the intrinsic motivation of the students (Elliot \& Murayama, 2009).

\section{Limitations and Questions for Future Research}

This research is not without limitations. First limitation is that this study did not separate the mastery and performance goals even though these are two different class variables. Given the small sample size of 60 regarding the classroom environment that children experience, only the reasons about why children exhibit different achievement behaviour in the same classroom situation can be speculated. However, future research 
can take this into consideration. Also, it is important to look into the link between the implicit views of the students about intelligence and their achievement motivation as suggested by Leondari \& Gialamas (2002) that the students orient themselves with either mastery or performance goals according to the views they hold about intelligence. Dweck \& Leggett (1988), has correctly defined "A consistent predictor of children's goal orientation is their theory of intelligence" (as cited in Leondari \& Gialamas, 2002).

The second limitation is that classroom goal structure was used as an independent variable in this study. In fact, most of these researchers have taken goal structure as an independent variable in their study and tried to link them with other variables. However, the most important area to consider is to look at the classroom goal structure as a mediating variable and see how it affects the relationship between the teaching strategies of the teachers, particularly the assessment practices of the teachers and the achievement goal of the students at the academic setting.

Dweck's model does not propose that the achievement behaviour of the individuals is directly determined by his/her implicit theory of intelligence but this relationship is mediated by their goal orientation. Nevertheless, these goal orientations are determined by the learning structure or school, the environment which may include the perception of classroom context and the meaning the students attach to it from their classroom experiences (Dupeyrat C. \& Marine C., 2005). It can be posited that the level of cognitive engagement of the students in the academic setting is mediated by the goal structure which ultimately affects the achievement goal of the students. Therefore, an important area of research will be to look into the goal structure of the individuals as a mediating variable and how it affects the achievement goal of the students.

The third limitation of this research is that the hypothesized statement that promoting interaction will have an impact on students' intrinsic motivation was not confirmed as suggested by the previous researchers. However, the correlation between classroom goal structure and the students' intrinsic motivation was confirmed. For this reason, it is necessary for the future researcher to identify the mediating variable and the role it plays in determining a strong relationship between these two variables, that is, classroom goal structure and intrinsic motivation.

Though the present research has some limitations, it contributes to the motivation and the effect of classroom environment by addressing how students perceive the classroom goal environment and how it further influences them in developing personal goal orientations in the academic settings. Furthermore, it has posed challenges to the future researchers to examine the link between the classroom goal structure and intrinsic motivation of the students by identifying a mediating variable between these two variables. This research has highlighted on the different aspects of classroom that affect the students' intrinsic motivation. In order to further examine the causes of differences in students' perceptions, we need to have knowledge about classroom goal structures, teacher practices and students' overt behaviour. However, both are needed to build a more comprehensive view on the interaction between a person and a context (Tapola \& Niemivirta, 2008).

\section{Conclusion}

In a secondary school the teachers stresses on both mastery and performance goals and accordingly the students orient to different type of goals which ultimately affect the intrinsic motivation of the students. The classroom environment has a high influence on the students in determining their achievement goals. As such, the teaching strategies of the teachers in the classroom, especially, their assessment practices need to be taken into consideration because it is one of the aspects of classroom environment that influences the students' achievement goal.

We should also focus on the motivation (both intrinsic and extrinsic) of the students considering the individual differences because it affects the achievement outcome of the students. The teacher in the classroom should be aware of both personal and contextual factors that might be affecting students' perceptions of the teaching practices as these perceptions may further influence motivation and learning of the students (Pulkka \& Niemivirta, 2013). Nevertheless, the students in the classroom may not orient themselves or even perceive to any type of achievement goals (Yperen, 2006). In this regard, teachers can promote learning or mastery goals as it is believed to have more positive impact on the academic achievement of the students (Tollefson, 2000). The classroom context created by the teacher interacts with the students' perception and their personal goals which further affects their achievement outcomes (Pintrich, 2003). Having a goal is favourable but it needs to be fit in with students' self-belief but it can be fostered through teachers' encouragement (Rendall et al., 2011). Therefore, the teachers in the classroom should be conscious of both personal and contextual factors that affect students' perceptions of the classroom environment created by them as these perceptions may have a high influence on students' motivation and learning. 
In conclusion, Achievement goal researchers and theorists have been largely dependent on the performance and mastery goals dichotomy trying to explain the achievement behaviour of the students in the academic settings. Infact, many years has been spent by goal theorists such as Dweck in an attempt to research various aspects of academic performances and experiences of the students in the classroom and how these determine their achievement in the academic settings. Nonetheless, educators can play an effective role by improving their teaching strategies and in this way help in increasing students' achievement motivation based on Dweck's research. Hence, the teachers in the classroom need to emphasise more on effort and in this way the students might be motivated to learn and this may ultimately enhance their academic achievement (Shaughnessy \& Moore, 2012). The educators need to understand that the most critical influences on students' level of cognitive engagement or their choice of cognitive strategies in the academic settings is their motivation to learn.

\section{References}

Alkharusi, H. (2008). Effects of classroom assessment practices on students' achievement goals. Educational Assessment, 13, 243-266. https://doi.org/10.1080/10627190802602509

Alkharusi, H. (2010). Teachers' assessment practices and students' perceptions of the classroom assessment environment. World Journal on Educational Technology, 2(1), 27-41.

Alkharusi, H. (2010). Literature review on achievement goals and classroom goal structure: implications for future research. Electronic Journal of Research in Educational Psychology, 8(3), 1363-1386.

Alkharusi, H. (2010). Validation of the trichotomous framework of achievement goals for Omani students. Educational Research Journal, 25(2).

Ames, C., \& Archer, J. (1988). Achievement goals in the classroom: students' learning strategies and motivation processes. Journal of Educational Psychology, American Psychological Association, 80(3), 260-267. https://doi.org/10.1037/0022-0663.80.3.260

Ames, C. (1992). Classrooms: Goals, structures, and student motivation. Journal of Educational Psychology, American Psychological Association, 84(3), 261-271. https://doi.org/10.1037/0022-0663.84.3.261

Anderman, E.M., \& Midgley, C. (1997). Changes in achievement goal orientations, perceived academic competence, and grades across the transition to middle-level schools. Contemporary Educational Psychology, 22, 269-298. https://doi.org/10.1006/ceps.1996.0926

Baron, R. M., \& Kenny, D. A. (1986). The moderator-mediator variable distinction in social psychological research: Conceptual, strategic and statistical considerations. Journal of Personality and Social Psychology, American Psychological Association, 51(6), 1173-1182. https://doi.org/10.1037/0022-3514.51.6.1173

Barron, K.E., Harackiewicz, J.M., Carter, S.M., Lehto, A.T., \& Elliot, A.J. (1997). Predictors and consequences of achievement goals in the college classroom: Maintaining interest and making the grade. Journal of Personality and Social Psychology, American Psychological Association, 73(6), 1284-1295. https://doi.org/10.1037/0022-3514.73.6.1284

Belanger, J.J., Lafreniere, M.-A. K., Vallerand, R.J., \& Kruglansky, A. W. (2013). Driven by fear: The effect of success and failure information on passionate individual's performance. Journal of Personality and Social Psychology, American Psychological Association, 104(1), 180-195. https://doi.org/10.1037/a0029585

Blackwell, L.S., Trzesniewski, K.L., \& Dweck, C.S. (2007). Implicit theories of Intelligence predict achievement across an adolescent transition: A longitudinal study and an intervention. Child Development, 78(1), 246-263. https://doi.org/10.1111/j.1467-8624.2007.00995.x

Brookhart, S.M., \& Durkin, D.T. (2003). Classroom assessment, student motivation, and achievement in high school social studies classes. Applied Measurement in Education, 16(1), 27-54. https://doi.org/10.1207/S15324818AME1601_2

Ciani, K.D., Sheldon, K.M., Easter, M.A., \& Hilpert3, J.C. (2011). Antecedents and trajectories of achievement goals: A self-determination theory perspective. British Journal of Educational Psychology, The British Psychological Association, 81, 223-243. https://doi.org/10.1348/000709910X517399

Covington, M.V. (2000). Goal, theory, motivation, and school achievement: An integrated review. Annual Review of Psychology, 51, 171-200. https://doi.org/10.1146/annurev.psych.51.1.171

Deemer, S.A. (2004). Using achievement goal theory to translate psychological principles into practice in the secondary classroom. American Secondary Education, 32(3), 4-15. 
Dupeyrat, C., \& Marine, C. (2005). Implicit theories of intelligence, goal orientation, cognitive engagement, and achievement: A test of Dweck's model with returning to school adults. Contemporary Educational psychology, 30, 43-59. https://doi.org/10.1016/j.cedpsych.2004.01.007

Dweck, C.S., \& Elliot, A.J. (2005). Competence and motivation: Competence as the core of achievement motivation. In A.J. Elliot \& C.S. Dweck (Eds.) Handbook of competence and motivation, (pp. 3-12) New York; The Guildford Press.

Dweck, C.S., \& Grant, H. (2003). Clarifying achievement goal and their impact. Journal of Personality and Social Psychology, 85(3), 541-553. https://doi.org/10.1037/0022-3514.85.3.541

Dweck, C.S., \& Leggett, E.L. (1988). A Social-Cognitive approach to motivation and personality. Psychological Review, American Psychological Association, 95(2), 256-273. https://doi.org/10.1037/0033-295X.95.2.256

Elliot, A.J., \& Church, M.A. (1997). A hierarchical model of approach and avoidance achievement motivation. Journal of Personality and Social Psychology, American Psychological Association, 72(1), 218-232. https://doi.org/10.1037/0022-3514.72.1.218

Elliot, A.J. (1999). Approach and avoidance motivation and achievement goals. Educational Psychologist, 34(3), 169-189. https://doi.org/10.1207/s15326985ep3403_3

Elliot, A.J., McGregor, H.A., \& Gable, S. (1999). Achievement goals, study strategies, and exam performance: A mediational analysis. Journal of Educational Psychology, 91(3), 549-563. https://doi.org/10.1037/0022-0663.91.3.549

Elliot, A.J., \& Murayama, K. (2012). The competition-performance relation: A meta-analytical review and test of the opposing processes model of competition and performance. Psychological Bulletin, American Psychological Association, 138(6), 1035-1070.

Elliot, A.J., \& Rawsthorne, L.J. (1999). Achievement goals and intrinsic motivation: A meta-analytic review. Personality and Social Psychology Review, 3(4), 326-344. https://doi.org/10.1207/s15327957pspr0304_3

Elliot, A.J., \& Sheldon, K.M. (1999). Goal striving, need satisfaction, and longitudinal well-being: The self-concordance model. Journal of Personality and Social Psychology, American Psychological Association, 76(3), 482-497. https://doi.org/10.1037/0022-3514.76.3.482

Elliot, A.J. (2005). A conceptual history of the achievement goal construct. In A.J. Elliot \& C.S. Dweck (Eds.) Handbook of competence and motivation, (pp. 52-72) New York; The Guildford Press.

Elliot, A., Cury F., Sarrazin, P., Fonseca, D.D., \& Rufo, M. (2002). The trichotomous achievement goal model and intrinsic motivation: A sequential mediational analysis. Journal of Experimental Social Psychology, 38, 473-481. https://doi.org/10.1016/S0022-1031(02)00017-3

Elliot, A.J., \& Conroy, D.E. (2004). Fear of failure and achievement goals in sport: Addressing the issue of the chicken and the egg. Anxiety, Stress, and Coping, 17(3), 271-285. https://doi.org/10.1080/1061580042000191642

Elliot, A.J., \& Harackiewicz, J.M. (1996). Approach and avoidance achievement goals and intrinsic motivation: A mediational analysis. Journal of Personality and Social Psychology, 70(3), 461-475. https://doi.org/10.1037/0022-3514.70.3.461

Elliot, A.J., Harackiewicz, J.M., \& Barron, K.E. (1998). Rethinking achievement goals: When are they adaptive for college students and why? Educational Psychologist, 33(1), 1-21. https://doi.org/10.1207/s15326985ep3301_1

Elliot, A.J., \& Murayama, K. (2009). The joint influence of personal achievement goals and classroom goal structures on achievement-relevant outcomes. Journal of Educational Psychology, American Psychological Association, 101(2), 432-447. https://doi.org/10.1037/a0014221

Elliot, A.J., \& Thrash, T.M. (2002). Approach-avoidance motivation in personality: Approach and avoidance temperaments and goals. Journal of Personality and Social Psychology, American Psychological Association, 82(5), pp. 804-818. https://doi.org/10.1037//0022-3514.82.5.804

Elliot, A.J., \& Thrash, T.M. (2004). The intergenerational transmission of fear of failure. Personality of Social Psychology Bulletin, 30(8), 957-971. https://doi.org/10.1177/0146167203262024 
Hidi, S., \& Harackiewicz, J.M. (2000). Motivating the academically unmotivated: A critical issue for the $21^{\text {st }}$ century. Review of Educational Research Summer, 70(2), 151-179. https://doi.org/10.3102/00346543070002151

Hong, Y.Y., Chiu, C.Y., Dweck, C.S., \& Lin, D.M.S., \& Wan, W. (1999). Implicit theories, attributions, and coping: A meaning system approach. Journal of Personality and Social Psychology, 77(3), 588-599. https://doi.org/10.1037/0022-3514.77.3.588

James, V.H., \& Yates, S.M. (2007). Extending the multiple-goal perspective to tertiary classroom goal structures. International Education Journal, 8(2), 68-80.

Kaplan, A., \& Maehr, M.L. (2007). The contributions and prospects of goal orientation theory. Educational Psychological Review, 19, 141-184. https://doi.org/10.1007/s10648-006-9012-5

Ke, F. (2008). Computer games application within alternative classroom goal structures: Cognitive, metacognitive, and affective evaluation. Educational Tech Research Dev, 56, 539-556. https://doi.org/10.1007/s11423-008-9086-5

Kitsantas, A., Steen, S., \& Huie, F. (2009). The role of self-regulated strategies and goal orientation in predicting achievement of elementary school children. International Electronic Journal of Elementary Education, 2, $1-17$.

Leondari, A., \& Gialamas, V. (2002). "Implicit theories, goal orientations, and perceived competence: Impact on students' achievement behaviour". Psychology in the Schools, Wiley Periodicals, Inc., 39(3). https://doi.org/10.1002/pits.10035

Linnenbrink, E.A. (2005). The dilemma of performance-approach goals: The use of multiple goal contexts to promote students' motivation and learning. Journal of Educational Psychology, American Psychological Association, 97(2), 197-213. https://doi.org/10.1037/0022-0663.97.2.197

Locke, E.A., \& Latham, G.P. (2006). New directions in goal setting theory. Association for Psychological Science, 15(5), 265-268. https://doi.org/10.1111/j.1467-8721.2006.00449.x

McGregor, H.A., \& Elliot, A.J. (2002). Achievement goals as predictors of achievement-relevant processes prior to task engagement. Journal of Educational Psychology, 94(2), 381-395. https://doi.org/10.1037//0022-0663.94.2.381

Meece, J.L, Anderman, M.E, \& Anderman, H.L. (2006). Classroom goal structure, student motivation and academic achievement. Annual Review of Psychology, 57, 487-503. https://doi.org/10.1146/annurev.psych.56.091103.070258

Middleton, M.J., Kaplan, A., \& Midgely, C. (2004). The change in middle school students' achievement goals in mathematics over time. Social Psychology of Education, 7, 289-311. https://doi.org/10.1023/B:SPOE.0000037484.86850.fa

Midgely, C., Roeser, R.W, \& Urdan, T.C. (1996). Perceptions of the school psychological environment and early adolescents' psychological and behavioural functioning in school: The mediating role of goals and belonging. Journal of Educational Psychological, American Psychological Association, 88(3), 408-422.

Midgley, C., Kaplan, A., Middleton, M., \& Maehr, M.L. (1998). The development and validation of scales assessing students' achievement goal orientations. Contemporary Educational Psychology, 23, 113-131. https://doi.org/10.1006/ceps.1998.0965

Midgely, C., Maehr, M.L., Hruda, L.Z., Anderman, E., Anderman, L., Freeman, K.E., Gheen, M., Kaplan, A., Kumar, R., Middleton, M.J., Nelson, J., Roeser, R., \& Urdan, T. (2000). Manual for the patterns of adaptive learning scales. The University of Michigan.

Miller, S.A., Lam, H., Boe, J.L., Kumar, S. \& Jagacinski, C.M. (2010). Changes in achievement goals and competence perceptions across the college semester. Motivation Emotion, 34, 191-204. https://doi.org/10.1007/s11031-010-9165-x

Mueller, C.M., \& Dweck, C.S. (1998). Praise for intelligence can undermine children's motivation and performance. Journal of Personality and Social Psychology, American Psychological Association, 75(1), 33-52. https://doi.org/10.1037/0022-3514.75.1.33

Nitsche, S., Steuer, G., Fasching, M.S., Dresel, M., \& Dickhauser, O. (2013). Relations between teachers' goal orientations, their instructional practices and students' motivation. Psychology, 4(7), 572-584. https://doi.org/10.4236/psych.2013.47083 
Ohtani, K., Okada, R., Ito, T., \& Nakaya, M. (2013). A multilevel analysis of classroom goal structures' effects on intrinsic motivation and peer modelling: Teachers' promoting interaction as a classroom level mediator. Psychology, 4(8), 629-637. https://doi.org/10.4236/psych.2013.48090

O'Keefe, P.A. (2009). The situational adaptiveness of implicit theories of intelligence and achievement goal orientations. Department of Psychology and Neuroscience in the Graduate School of Duke University, 1-82.

Pekrun, R., Elliot, A.J., \& Maier, M.A. (2009). Achievement goals and achievement emotions: Testing a model of their joint relations with academic performance. Journal of Educational Psychology, 101(1), 115-135. https://doi.org/10.1037/a0013383

Pintrich, P.R. (2000). An Achievement Goal Theory Perspective on Issues in Motivation Terminology, Theory, and Research. Contemporary Educational Psychology, 25, 92-104. https://doi.org/10.1006/ceps.1999.1017

Pintrich, P.R., Conley, A.M.M., \& Kempler (2003). Current issues in achievement goal theory and research. International Journal of Educational Research, 39, 319-337. https://doi.org/10.1016/j.ijer.2004.06.002

Pulkka, A. T., \& Niemivirta, M. (2013). Adult students' achievement goal orientations and evaluations of the learning environment: A person-centred longitudinal analysis. Educational Research and Evaluation, 19(4), 297-322. https://doi.org/10.1080/13803611.2013.767741

Rendall, N.M.D., \& Wesson, C.J. (2011). Self-beliefs and student goal achievement. Psychology Teaching Review. The British Psychological Society, 17(1).

Rendall, N.M.D., Wesson, C., Anderson, L., \& Bould, E. (2009). Students' goal achievement: Exploring individual and situational factors. Electronic Journal of Research in Educational Psychology, 7(3), 1031-1052.

Roeser, R.W., Midgely, C., \& Urdan, T.C. (1996). Perceptions of the school psychological environment and early adolescents' psychological and behavioural functioning in school: The mediating role of goals and belonging. Journal of Educational Psychology, American Psychological Association, 88(3), 408-422. https://doi.org/10.1037/0022-0663.88.3.408

Ryan, A.M., \& Patrick, H. (2001). The classroom social environment and changes in adolescents' motivation and engagement during middle school. American Educational Research Journal, 38(2), 437-460. https://doi.org/10.3102/00028312038002437

Shaughnessy, M.F., \& Moore T.M.B. (2012). Carol Dweck's views on achievement and intelligence: Implications for education. Research Journal in Organizational Psychology \& Educational Studies, 1(3), 174-184.

Schultheiss, O.C., \& Brunstein, J.C. (2005). An implicit motive perspective on competence. In A.J. Elliot \& C.S. Dweck (Eds.) Handbook of competence and motivation, (pp. 31-51) New York; The Guildford Press.

Schwinger, M., \& Pelster, S.J. (2011). Performance-approach and performance-avoidance classroom goals and the adoption of personal achievement goals. British Journal of Educational Psychology, The British Psychological Society, 81, 680- 699. https://doi.org/10.1111/j.2044-8279.2010.02012.x

Senko, C., Hulleman, C.S., \& Harackiewicz, J.M. (2011). Achievement goal theory at the crossroads: Old controversies, current challenges, and new directions. Educational Psychologist, 46(1), 26-47. https://doi.org/10.1080/00461520.2011.538646

Sternberg, R.J. (2005). Intelligence, Competence, and Expertise. In A.J. Elliot \& C.S. Dweck (Eds.) Handbook of competence and motivation, (pp. 15-30) New York; The Guildford Press.

Tanaka, A., Okuno, T., \& Yamauchi, H. (2013). Longitudinal tests on the influence of achievement goals on effort and intrinsic motivation in the workplace. Motivation Emotion, 37, 457-464. https://doi.org/10.1007/s11031-012-9318-1

Tapola, A., \& Niemivirta, M. (2008). The role of achievement goal orientations in students' perceptions of and preferences for classroom environment. British Journal of Educational Psychology, The British Psychological Society, 78, 291-312. https://doi.org/10.1348/000709907X205272

Tollefson, N. (2000). Classroom applications of cognitive theories of motivation. Educational Psychological Review, 12(1). https://doi.org/10.1023/A:1009085017100 
Urdan, T., \& Schoenfelder, E. (2006). Classroom effects on student motivation: Goal structures, social relationships, and competence beliefs. Journal of Social Psychology, 44, 331-349. https://doi.org/10.1016/j.jsp.2006.04.003

Was, C. (2006). Academic achievement goal orientation: Taking another look. Electronic Journal of Research in Educational Psychology, 4(3), 10, 529-550.

Wentzel, K.R. (2000). What is it that I'm trying to achieve? Classroom goals from the content perspective. Contemporary Educational Psychology, 25, 105-115. https://doi.org/10.1006/ceps.1999.1021

Winne, P.H., \& Nesbit, J.C. (2010). The psychology of academic achievement. Annual Review of Psychology, 61, 653-78. https://doi.org/10.1146/annurev.psych.093008.100348

Wolters, C.A., \& Daugherty, S.G. (2007). Goal structures and teachers' sense of efficacy: Their relation and association to teaching experience and academic level. Journal of Educational Psychology, American Psychological Association, 99(1), 181-193. https://doi.org/10.1037/0022-0663.99.1.181

Yperen, N.W.V. (2006). A novel approach to assessing achievement goals in the context of the 2x2 framework: Identifying distinct profiles of individuals with different dominant achievement goals. Personality of Social Psychology Bulletin, 32(11), 1432-1445. https://doi.org/10.1177/0146167206292093

\section{Copyrights}

Copyright for this article is retained by the author(s), with first publication rights granted to the journal.

This is an open-access article distributed under the terms and conditions of the Creative Commons Attribution license (http://creativecommons.org/licenses/by/4.0/). 